\section{Tung dokumentasjon om alkohol og skader}

Verdens helseorganisasjon Alcohol and injuries

Emergency department studies in an international perspective. 286 s, tab. Genève: WHO, 2009. Pris CHF 50 ISBN 978-92-4-154784-0

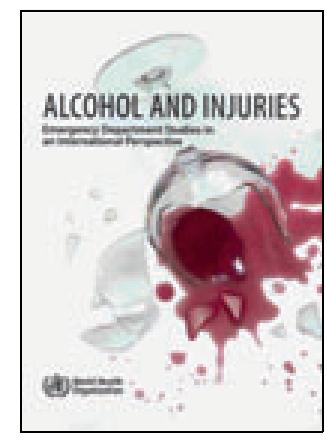

Alkohol bidrar på verdensbasis til ca. $4 \%$ av den såkalte «burden of disease», et omfang i størrelsesorden ikke langt fra tobakk. Omkring en tredel av denne belastningen på pasienter og behandlings-

apparat utgjøres av traumatiske skader. Dette er tall som viser seg i praksis i akuttmottak og på legevakter verden over, i form av omfattende lidelse og store ressurser som går med til behandling. Det er gode grunner til å anta at den nordeuropeiske måten å drikke alkohol på, gjør at andelen av traumatiske skader er høyere her.

Verdens helseorganisasjon tar mål av seg til å gi en aktuell oversikt over kunnskapsstatus for sammenhengen mellom alkohol og traumatiske skader. Et utvalg av artikler fra sentrale forskere på feltet blir presentert, og de nyeste referansene er fra 2008. Boken er oversiktlig inndelt i fem seksjoner: Epidemiologiske studier om alkohol og skader, Metodiske utfordringer knyttet til forskning i akuttmottak, Identifisering av alkoholrelaterte skader, Kartlegging og kort intervensjon og Konsekvenser denne kunnskapen kan få i ulike kulturer eksemplene er fra Mexico, Polen, Tsjekkia, India og Argentina.

Forskningsresultatene som formidles, viser at dette er et fagfelt der skadeomfanget er stort, men dessverre også at klinikernes kunnskaper og ferdigheter i kartlegging og intervensjon er begrensede. Nyere forskning tyder imidlertid på at det finnes gode metoder, f.eks. innenfor kort intervensjon, som ville gitt gode resultater, gitt en rutinemessig gjennomføring.

I forordet står det at boken er skrevet for forskere, klinikere og politiske beslutningstakere. Jeg skulle ønske dette var tilfelle, fordi det er viktig kunnskap som man formidler. I to velskrevne oppsummeringartikler tar man for seg kliniske og forskningsmessige implikasjoner av rapporten i europeisk og global sammenheng. Det er også artikler som er svært klinisk relevante, særlig i fjerde seksjon, f.eks. kapittel 12: En pragmatisk implementering av kort intervensjon. I denne artikkelen beskriver man erfaringer fra St. Mary's Hospital i London der systematisk intervensjon synes å kunne forebygge annenhver reinnleggelse. Her anbefaler man bl.a. at spesialutdannede sykepleiere kartlegger og gir råd til pasienter som blir henvist for en alkoholrelatert skade. En liknende intervensjonsmodell er under etablering i Norge, ved Stavanger universitetssjukehus.

På tross av disse kapitlene er nok målgruppen likevel mer forskere enn andre grupper. Jeg savner bl.a. populariserte sammendrag, der helsepolitiske utfordringer og anbefalinger kunne vært formulert på en mer tilgjengelig måte. Dette kunne gitt politikere grunnlag for å understøtte en mer omfattende prioritering av dette feltet. Klinikere kan finne anbefalinger av kunnskapsbaserte metoder og få mange gode verktøy for bedre kartlegging, og forskere kan nærmest boltre seg i velavgrensede problemstillinger til videre forskning $i$ et fagfelt der vi vet så altfor lite.

\section{Svein Skjøtskift}

Psykiatrisk divisjon

Haukeland universitetssykehus

\section{God bok om kolorektal kreft}

Susan Gearhart, Nita Ahuja, red.

\section{Colorectal cancer}

Early diagnosis and treatment of cancer. 278 s, tab, ill. Philadelphia, PA: Saunders Elsevier, 2010. Pris EUR 110

ISBN 978-1-4160-4686-8

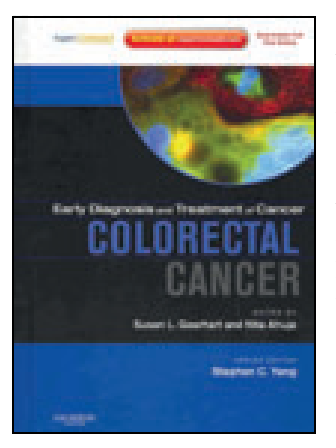

Dette er en god bok om kolorektal kreft. Den inngår i en serie om tidlig diagnostikk og behandling av kreft. Redaktørene kommer fra et faglig tungt miljø i kirurgi og onkologi ved Johns Hopkins University, Maryland, USA. Av i alt 32 forfattere som har bidratt (alle fra USA), er 22 fra Johns Hopkins. Boken er altså først og fremst skrevet av og for fagfolk i USA, men det meste er meget relevant også for norske forhold.

Boken omhandler epidemiologi, arvelig kreft, genetisk screening, primærforebygging (livsstil, kosthold, kjemoprevensjon), befolkningsscreening, preoperativ evaluering, kirurgisk teknikk, kjemo- og stråleterapi, vaksiner og immunterapi, oppfølging og pasientens behov etter primærbehandling («kunsten å leve med kreft»). Kapitlene er godt skrevet, lettleste med tiltalende layout og illustrasjoner.

Fra et norsk perspektiv vil jeg trekke frem kapitlene om arvelig kreft som de mest instruktive for klinikere som ikke er spesialister på området, men som i hvert fall ukentlig blir konfrontert med spørsmålet: «Er dette arvelig?». Kapitlene om screening henviser mye til amerikanske retningslinjer og er ikke oppdatert på opptil ett år gamle forskningsresultater. Formildende kan man si at forskning er ferskvare og at det kan bli vanskelig å få med helt oppdaterte gjennombruddsresultater i bøker om tema hvor det skjer en rask utvikling. Alt $i$ alt en meget god bok som jeg anbefaler.

Geir Hoff

Kreftregisteret

\section{Anmeldelser i Tidsskriftet}

Anmeldelser av bøker og andre medier er en viktig del av Tidsskriftet og skal være til hjelp i avgjørelser om hvilke bøker eller medier som bør anskaffes.

Ta kontakt med redaksjonen på tidsskriftet@legeforeningen.no dersom du har tips om en bok eller annet du mener bør anmeldes eller som du selv ønsker å anmelde. 